\title{
Phelipanche aegyptiaca Management with Glyphosate in Potato
}

\author{
Mustapha Haidar*, Elie Shdeed \\ American University of Beirut, Beirut, Lebanon \\ Email: ${ }^{*}$ mhaidar@aub.edu.lb
}

Received 17 August 2015; accepted 11 October 2015; published 14 October 2015

Copyright (C) 2015 by authors and Scientific Research Publishing Inc.

This work is licensed under the Creative Commons Attribution International License (CC BY).

http://creativecommons.org/licenses/by/4.0/

(c) (i)

\begin{abstract}
Two years field and greenhouse studies were carried out to evaluate the efficacy of sub-lethal doses of glyphosate (Round $\mathrm{up}^{\mathrm{R}}$ ), ammonia gas, phosphoric acid and sulfuric acid against Phelipanche aegyptiaca in potato. Results showed that sequential application of sub-lethal doses of glyphosate at all tested rates significantly reduced $P$. aegyptiaca shoot number and shoot dry weight. While, the use of ammonia gas, phosphoric acid and sulfuric acid had no significant effect on the total level of $P$. aegyptiaca infection as compared to the control. The best results considering both $P$. aegyptiaca control and selectivity in potato were obtained by sequential application of sub-lethal doses of glyphosate at 60 and $80 \mathrm{~g} \cdot \mathrm{ai}^{\cdot \mathrm{ha}^{-1}}$. Sequential application of glyphosate at 60 g-ai'ha ${ }^{-1}$ reduced $P$. aegyptiaca infection by $100 \%$ after 100 days after potato emergence (DAPE). Except for sequential application of glyphosate at 60 and $80 \mathrm{~g} \cdot \mathrm{ai}^{-h^{-1}} \mathrm{a}^{-1}$ all tested rates enhanced the maturity rate of potato plants and decreased the number of marketable potato tubers.
\end{abstract}

\section{Keywords}

Ammonia Gas, Glyphosate, Phelipanche aegyptiaca, Phosphoric Acid, Potato, Sulfuric Acid

\section{Introduction}

Potato (Solanum tuberosum) is considered one of the most important strategic crops in the Mediterranean region. In Lebanon, the Beq'aa and Akkar provinces are the main potato producing areas in the country, with about $68 \%$ and $19 \%$ of the total production, respectively [1]. Potato is susceptible to several pests among which P. aegyptiaca. This parasitic weed parasitizes summer, spring and autumn planted potatoes across Lebanon and the Mediterranean region.

Phelipanche aegyptiaca Forsk (Branched broomrape) is an aggressive root holoparasite that infects roots of

\footnotetext{
${ }^{*}$ Corresponding author.
} 
various dicotyledous plants. This parasite is an invasive insidious higher plant in Lebanon and the Mediterranean region; it causes severe yield losses in Solanaceae and Fabaceae crops [2]-[4]. Severe reduction in potato yield quantity and quality were observed due to high levels of $P$. aegyptiaca field infestations in Lebanon [4] [5]. Management of $P$. aegyptiaca remains challenging for potato producers. With variable degrees of success, several control methods have been tested against Phelipanche spp. infection including physical, cultural, chemical, soil solarization, trap and catch crops, resistant varieties, synthetic germination stimulants and soil amendments [3] [6]-[13].

One of the most promising methods for controlling Phelipanche spp. is the use of sub-lethal doses of glyphosate on crops that show tolerance to glyphosate [3] [7] [8]. The plan is to spray sub-lethal doses of glyphosate on the potato leaves (POE) early in the season, so that the glyphosate would move through the crop phloem to underground Phelipanche spp. attachments on the crop roots and inhibit Phelipanche spp. growth prior to its above ground shoot emergence. Sub-lethal doses of glyphosate were found to be effective against Phelipanche spp. in broad bean [14], sunflower [15], tomato [16], carrot and celery [8] and vetch [17]. Thus, the use of sub-lethal doses of glyphosate as potential and economical method to control Phelipanche spp. has become increasingly important. To our knowledge, the use of sub-lethal doses of glyphosate against $P$. aegyptiaca has not been confirmed in potato, most likely because of its limited selectivity, rate, and timing of application.

Inorganic compounds have also been shown to reduce Phelipanche spp. growth. Many researchers showed that high nitrogen fertilizers $\left(\mathrm{NH}_{4} \mathrm{NO}_{3}\right)$ and sulfur powder reduced Phelipanche spp. growth and development [10] [18] [19]. However, our literature search revealed no published work on the effect of ammonia gas, phosphoric acid and sulfuric acid against $P$. aegyptiaca. Acidifying irrigation water may aid in creating optimum soil $\mathrm{pH}$ for various crop growth [20] by mitigating a small zone from where the crop roots can better obtain nutrients. A pH range of 5.5 to 6.5 is considered ideal for most crops including potato [20], but may not be for Phelipanche spp. because the parasite is commonly distributed in alkaline soils [3]. Most soils in the Beq'aa plain are calcareous in nature with a $\mathrm{pH}$ ranging between 7.5 and 8.5 and are thus amenable to $P$. aegyptiaca infestation.

The main objectives of the present work were to examine: a) $P$. aegyptiaca control using ammonia gas, phosphoric acid, sulfuric acid or sub-lethal doses of glyphosate; b) optimal rates of glyphosate application for $P$. aegyptiaca control; and c) response of potato to sub-lethal doses of glyphosate.

\section{Materials and Methods}

\subsection{Greenhouse Experiment}

A single greenhouse experiment was done at the greenhouse area of the Faculty of Agricultural Sciences at the Beirut Coastal area, during September 2009 and April 2010. Phelipanche aegyptiaca seeds were collected in 2008 from various potato fields in the Beq'aa plain and stored at room temperature. Potato tubers (cultivar Spunta) were spread on paper sheets and kept moist in the lab at room temperature three weeks prior to planting. Boxes were filled with a mixture of potting soil, perlite and peat moss at a rate of 1:1:1, inoculated with $100 \mathrm{mg}$ of $P$. aegyptiaca seeds, and irrigated with water for a period of two weeks prior to planting potato to allow for conditioning of $P$. aegyptiaca seeds. Two tubers were planted in plastic netted boxes $30 \times 40 \times 30 \mathrm{~cm}$.

Methyl bromide was injected in the boxes prior to planting potato tubers. Methyl bromide was selected as another $100 \%$ free $P$. aegyptiaca control (comparison with inorganic chemicals). Four moist boxes containing $P$. aegyptiaca seeds were placed in an area of $10 \mathrm{~m}^{2}$ covered with nylon sheet and fumigated with methyl bromide at a rate of $900 \mathrm{~g}$ per $10 \mathrm{~m}^{2}$. Sheets were removed $24 \mathrm{hrs}$ after fumigation and boxes placed back in the greenhouse. Potato tubers were planted 20 days after fumigation.

Glyphosate (Round up ${ }^{\mathrm{R}}$, 48\%) was sprayed on potato leaves (POE) at a rate of 125, 135, and $150 \mathrm{~g} \cdot \mathrm{ai}^{\mathrm{i}} \mathrm{ha}^{-1}$ (no surfactant was added) in a spray volume of $1000 \mathrm{~L} \cdot \mathrm{ha}^{-1}$. Spraying rates were selected based on preliminary studies performed in our laboratory. Each rate was tested for single and sequential applications at 20, 40, and 60 DAPE (20, $20+40$ and $20+40+60$ DAPE). Potato plants were $12-18 \mathrm{~cm}$ tall at 20 DAPE. Spraying dates were selected based on previous experience with the species as well as on various other considerations. The underground stage of development of P. aegyptiaca in the soil is unknown [6], and seeds of the parasite in the soil keep on germinating continuously. Additionally, the best control strategy is to eliminate the parasite before it emerges above the soil [21]. Sulfuric acid or phosphoric acid was mixed with water to have a final solution of $\mathrm{pH}$ 2. Diluted solutions of sulfuric or phosphoric acid were then applied at a volume of one liter per box (irri- 
gated) every other week starting at the time of potato planting.

\subsection{Field Experiments General Procedure}

During the 2009 and 2010 spring seasons, field experiments were carried out at the Advancing Research Enabling Communities (AREC) of the American University of Beirut. The AREC is located in the Northern Central Beqa'a plain of Lebanon. A naturally infested field with P. aegyptiaca was used for both years (same field) but at different locations. The soil is a silty clay loam with a $\mathrm{pH}$ of 7.41 , Electrical Conductivity of $0.24 \mathrm{~ms} / \mathrm{m}$ and $2.4 \%$ organic matter. In both years, all plots were tilled twice with a mouldboard and disked two weeks before planting potato. The experimental area received a uniform application of $2.5 \mathrm{t} \cdot \mathrm{ha}^{-1}$ of NPK (15:15:15) during planting. Nitrogen (Ammonium nitrate, 33.5\%) was applied in bands 40 days after planting at a rate of 300 $\mathrm{kg} \cdot \mathrm{ha}^{-1}$. All plots were sprinkler-irrigated every six days to bring the soil back to field capacity (measured by using tensiometers at 0.33 bars suction). The standard certified potato cultivar "Spunta" was planted in both years at $3.0 \mathrm{t} \cdot \mathrm{ha}^{-1}$. Potato rows were $0.70 \mathrm{~m}$ apart and within-the-row spacing was around $0.25 \mathrm{~m}$. Plots were hilled 6 weeks after planting (standard practice by Lebanese farmers). To eliminate all weeds other than $P$. aegyptiaca, the entire experimental areas received a standard application of metribuzin (Sencor ${ }^{\mathrm{R}}, 70 \%, \mathrm{PE}$ ) at 0.75 $\mathrm{kg} \cdot \mathrm{ai} \cdot \mathrm{ha}^{-1}$ two weeks after potato sowing with a boom sprayer at a rate of $400 \mathrm{~L} \cdot \mathrm{ha}^{-1}$. Glyphosate was applied POE on potato plants at 20,40, and 60 DAPE $((20,20+40$ and $20+40+60)$. Glyphosate was sprayed by a hand held $\mathrm{CO}_{2}$-pressurized backpack sprayer that delivers $310 \mathrm{~L} \cdot \mathrm{ha}^{-1}$ at $138 \mathrm{Kpa}$ through a Teejet 8002 flat fan spray tips. Irrigation water was withheld for two days after each spraying.

\subsection{Field Experiment in Spring 2009}

Ammonia gas and sub-lethal doses of glyphosate were the only treatments tested against $P$. aegyptiaca. Ammonia gas was injected in the soil (at field capacity) at $30 \mathrm{~kg} \cdot \mathrm{ha}^{-1}$ one week prior to planting potato to a depth of $30-35 \mathrm{~cm}$. A tractor pulling a cylinder full with pressurized ammonia and connected to the injection system which released the ammonia gas at a pressure of 2 - 3 bars in the soil was used. The field was then lightly irrigated to avoid evaporation of the gas. During the initial potato growth and in other plots, sequential application of foliar sub-lethal doses of glyphosate at a rate of $125 \mathrm{~g} \cdot \mathrm{ai} \cdot \mathrm{ha}^{-1}$ was applied on potato plants at 20, 40, and 60 DAPE (20, $20+40$ and $20+40+60$ ). Experimental plots ( $20 \mathrm{~m}$ long and $10 \mathrm{~m}$ wide) were arranged in a randomized complete block design with three replications. Each replicate or plot consists of 12 rows.

\subsection{Field Experiment in 2010}

Sub-lethal doses of glyphosate at 60,80 , and $100 \mathrm{~g} \cdot$ ai $\mathrm{ha}^{-1}$ were the only treatments tested against $P$. aegyptiaca. These rates were selected according to the results obtained from previous field and greenhouse experiments. All rates were tested for single and sequential application at 20,40, and 60 DAPE $(20,20+40$ and $20+40+60)$. A factorial experiment was used. Experimental plots (6 m long and $2.1 \mathrm{~m}$ wide) were arranged in a randomized complete block design with four replications.

\subsection{Experimental Measurements and Statistical Analyses}

Phelipanche aegyptiaca infection in the greenhouse experiment was assessed by counting emerged shoots and underground attachments and measuring total dry weight per box. At the end of the experiment, emerged P. aegyptiaca shoots (above ground) were counted and pulled out. Underground shoots were counted by washing the potato roots with water and separating remaining $P$. aegyptiaca attachments from potato roots. Phelipanche aegyptiaca infection in the field experiments was assessed by only counting emerged shoots (above ground) and measuring their total dry weight per $\mathrm{m}^{2}$ of the middle row in the field experiments. Potato data included number of plants per box/row (5 m), phytotoxicity visual rating according to the European Weed Research Council scoring system, height/two plants/box or ten plants/plot, total and marketable yield. Potato yield was determined by harvesting potato/box or part of the middle row in each plot $(5 \mathrm{~m})$. Yield quality was determined by separating harvested tubers into two classes: marketable ( $>6 \mathrm{~cm}$ diameter) and non-marketable tubers $(<5 \mathrm{~cm}$ in diameter). Statistical analyses were performed using SAS 9.2. (SAS Institute Inc., Cary, North Carolina USA). Data were analyzed statistically using ANOVA and Protected Least Significant Difference (LSD) Test at $p=0.05$ level of probability was used to determine significant differences between treatments means. 


\section{Results and Discussion}

\subsection{Greenhouse Experiment 2009/10}

Methyl bromide and single or sequential application of sub-lethal doses of glyphosate at 125, and $150 \mathrm{~g}$ ai/ha applied 20, 40, and 60 DAPE significantly reduced P. aegyptiaca total shoot number (above and underground) and total shoot dry weight 100 DAPE compared to the control (Table 1) All these treatments reduced P. aegyptiaca infection by $100 \%$. Sequential application of glyphosate at all tested rates significantly reduced shoot and dry weight of $P$. aegyptiaca 100 DAPE compared to the control. Sulfuric acid and phosphoric acid had no significant effect on $P$. aegyptiaca shoot number or total dry weight in comparison to the controls (Table 1).

Using sub-lethal doses of systemic herbicides as single or sequential applications have been found very effective against Phelipanche spp. in various crops. Split application with low rates of sulfunylurea herbicides inhibited $P$. aegyptiaca growth in potato [22] and tomato [12]. Sequential application of sub-lethal doses of glyphosate inhibited Phelipanche spp. growth in many crops [8] [14] [23].

The significance of using sequential application of systemic herbicides such as glyphosate on potato early in the season is to inhibit $P$. aegyptiaca growth prior to shoot emergence. Phelipanche aegyptiaca seeds are continuously induced to germinate by potato roots and develop the attachment organ, the germ tube or radicle. Sequential application of systemic herbicides may prevent the attachment of the organ or its differentiation and allow for early season control of the parasite.

Injection with methyl bromide was suggested as a control strategy for Phelipanche spp. by various scientists, showing effectiveness of methyl bromide in controlling and eradicating $P$. ramosa [24] [25] [26]. Although methyl bromide is very effective in eradicating and killing Phelipanche spp., it is not economical for broad application, and poses significant environmental impacts [27].

The observed low efficiency of phosphoric and sulfuric acid in mitigating against $P$. aegyptiaca infection could be because of low concentrations applied to the boxes or because of leaching from the boxes. However, these results contradict previous findings that report that soil $\mathrm{pH}$ affects seed germination and development [20]. Jain and Foy [28] found that preconditioning of P. aegyptiaca seeds with phosphoric acid (21 $\mathrm{ml}$ of 1 Molar stock solution) decreased the parasite seed germination in tomato.

Table 1. Effect of glyphosate, sulfuric acid, phosphoric acid, and methyl bromide on Phelipanche aegyptiaca above and underground shoot number (SN) and total shoot dry weight (TSDWT) 100 DAPE. Data represent average of four replicates (boxes). Means followed by the same letter, within each column, do not significantly differ at the $5 \%$ level according to the LSD test. DAPE: Days after potato emergence.

\begin{tabular}{|c|c|c|c|c|c|c|c|c|}
\hline Treatment & Rate & Application time & \multicolumn{4}{|c|}{ SN } & \multirow{2}{*}{\multicolumn{2}{|c|}{$\begin{array}{c}\text { TSDWT } \\
\text { (g) }\end{array}$}} \\
\hline \multirow[b]{2}{*}{ Glyphosate $\left(\mathrm{g} \cdot \mathrm{ai} \cdot \mathrm{ha}^{-1}\right.$ ) } & \multirow[b]{2}{*}{125} & \multirow{2}{*}{$\frac{(\mathrm{DAPE})}{20}$} & \multicolumn{2}{|c|}{ above ground } & \multicolumn{2}{|c|}{ underground } & & \\
\hline & & & 0 & $\mathrm{~b}$ & 0 & $\mathrm{~b}$ & 0 & $\mathrm{~b}$ \\
\hline & 135 & 20 & 5 & $\mathrm{ab}$ & 4.3 & $\mathrm{ab}$ & 2 & $\mathrm{ab}$ \\
\hline & 150 & 20 & 0 & $\mathrm{~b}$ & 0 & $\mathrm{~b}$ & 0 & $\mathrm{~b}$ \\
\hline & 125 & $20 / 40$ & 0 & $\mathrm{~b}$ & 0 & $\mathrm{~b}$ & 0 & $\mathrm{~b}$ \\
\hline & 135 & $20 / 40$ & 0 & $\mathrm{~b}$ & 0 & $\mathrm{~b}$ & 0 & $\mathrm{~b}$ \\
\hline & 150 & $20 / 40$ & 0 & $\mathrm{~b}$ & 0 & $\mathrm{~b}$ & 0 & $\mathrm{~b}$ \\
\hline & 125 & $20 / 40 / 60$ & 0 & $\mathrm{~b}$ & 0 & $\mathrm{~b}$ & 0 & $\mathrm{~b}$ \\
\hline & 135 & $20 / 40 / 60$ & 0 & $\mathrm{~b}$ & 0 & $\mathrm{~b}$ & 0 & $\mathrm{~b}$ \\
\hline & 150 & $20 / 40 / 60$ & 0 & $\mathrm{~b}$ & 0 & $\mathrm{~b}$ & 0 & $\mathrm{~b}$ \\
\hline Sulfuric acid & 2L/box & & 14.8 & $\mathrm{a}$ & 14.8 & $\mathrm{a}$ & 2.6 & $\mathrm{ab}$ \\
\hline Phosphoric acid & 2L/box & & 10.0 & $\mathrm{a}$ & 12.3 & a & 2.8 & $\mathrm{ab}$ \\
\hline Methyl Bromide & $900 \mathrm{~g} / 10 \mathrm{~m}^{2}$ & & 0.0 & $\mathrm{~b}$ & 0.0 & $\mathrm{~b}$ & 0.0 & $\mathrm{~b}$ \\
\hline Control without Phelipanche & 0 & & 0.0 & $\mathrm{~b}$ & 0.0 & $\mathrm{~b}$ & 0.0 & $\mathrm{~b}$ \\
\hline Control with Phelipanche & 0 & & 17.8 & $\mathrm{a}$ & 12.3 & $\mathrm{a}$ & 4.6 & a \\
\hline
\end{tabular}


Single or sequential application of glyphosate at all tested rates were toxic to the potato plants and significantly reduced potato shoot height at 30 and 60 DAPE, compared to the control (Table 2). Sulfuric acid, phosphoric acid, and methyl bromide had no significant effect on potato plants compared to the control. Visual potato injury appeared 10 days after the first glyphosate application and included leaf yellowing, necrosis, plant stunting, and compact potato shoots. Phytotoxicity was clearly reflected in the tuber quality of potato yield grown for fresh market with a high incidence of deformed (cracked) and small tubers (Figures 1(A)-(D)).

It is well known that glyphosate translocates sympoplastically and apoplastically in plants [29] [30]. During initial tuber development, tubers accumulate photosynthetic assimilates produced by the leaves and other exogenous compounds such as glyphosate. Thus, the glyphosate effect may appear as yellowing or necrosis in young leaves and malformed tubers.

\subsection{Field Experiment 2009}

Data on the total number of $P$. aegyptiaca shoots indicate that sequential applications of glyphosate at 125 $\mathrm{g} \cdot \mathrm{ai} \cdot \mathrm{ha}^{-1}$ was very effective in reducing its infection as compared to ammonia gas and/or the control (Figure 2). Unlike ammonia gas, glyphosate reduced $P$. aegyptiaca shoot number by $97 \%$ and $99 \%$, after 60 and 80 DAPE respectively, compared to the control. In addition, the observed shoots were stunted and almost dead. It was shown that frequent spray of glyphosate completely controlled Phelipanche spp. in parsley [23] faba bean, tobacco and tomato [14].

The reasons for the low efficiency of ammonia gas in reducing $P$. aegyptiaca infection are not easily discernible. They could be because of escape of volatile ammonia from the soil upon injection or because of improper injection and distribution of the gas in the soil.

Results in Table 3 show that glyphosate had significantly increased total potato yield compared to the ammonia treatment and the control. Moreover, the total number of potato tubers was also significantly higher by 63\% in glyphosate treated plots than both the ammonia and the control plots. However, most potato tubers were small in size (non-marketable).

Table 2. Effect of glyphosate, sulfuric acid, phosphoric acid and methyl bromide on potato shoot height (PHT) and vigor (PVR). Data represent average of four replicates. Means followed by the same letter, within each column, do not significantly differ at the 5\% level according to the LSD test. DAPE: Days after potato emergence; PVR: Crop phytotoxicity visual rating with 0 indicating complete death and 10 no injury.

\begin{tabular}{|c|c|c|c|c|c|c|c|c|}
\hline \multirow{3}{*}{$\begin{array}{c}\text { Treatment rate } \\
\text { Glyphosate }\left(\mathrm{g} \cdot \mathbf{a i} \cdot \mathrm{ha}^{-1}\right)\end{array}$} & \multirow{3}{*}{$\begin{array}{l}\text { Rate } \\
125\end{array}$} & \multirow{3}{*}{$\begin{array}{c}\text { Application time } \\
\text { (DAPE) } \\
20\end{array}$} & \multicolumn{4}{|c|}{ PHT (cm) } & \multirow{2}{*}{\multicolumn{2}{|c|}{$\begin{array}{l}\text { PVR (\%) } \\
60 \text { DAPE }\end{array}$}} \\
\hline & & & \multicolumn{2}{|c|}{30 DAPE } & \multicolumn{2}{|c|}{60 DAPE } & & \\
\hline & & & 71.3 & $\mathrm{~b}$ & 70.8 & $\mathrm{~b}$ & 6.5 & $\mathrm{~b}$ \\
\hline & 135 & 20 & 66.3 & $\mathrm{~b}$ & 78.0 & $\mathrm{~b}$ & 6.8 & $\mathrm{~b}$ \\
\hline & 150 & 20 & 65.0 & $\mathrm{~b}$ & 70.8 & $\mathrm{~b}$ & 6.5 & $\mathrm{~b}$ \\
\hline & 125 & $20 / 40$ & 71.5 & $\mathrm{~b}$ & 76.0 & $\mathrm{~b}$ & 7.0 & $\mathrm{~b}$ \\
\hline & 135 & $20 / 40$ & 76.8 & $\mathrm{~b}$ & 82.8 & $\mathrm{~b}$ & 7.5 & $\mathrm{~b}$ \\
\hline & 150 & $20 / 40$ & 76.0 & $\mathrm{~b}$ & 75.8 & $\mathrm{~b}$ & 6.5 & $\mathrm{~b}$ \\
\hline & 125 & $20 / 40 / 60$ & 77.5 & $\mathrm{~b}$ & 80.3 & $\mathrm{~b}$ & 7.5 & $\mathrm{~b}$ \\
\hline & 135 & $20 / 40 / 60$ & 76.5 & $\mathrm{~b}$ & 83.3 & $\mathrm{~b}$ & 7.8 & $\mathrm{~b}$ \\
\hline & 150 & $20 / 40 / 60$ & 64.3 & $\mathrm{~b}$ & 69.8 & c & 6.5 & $\mathrm{~b}$ \\
\hline Sulfuric acid & 2L/box & & 92.3 & a & 104.8 & a & 9.0 & $\mathrm{a}$ \\
\hline Phosphoric acid & 2L/box & & 86.8 & a & 99.3 & $\mathrm{a}$ & 8.8 & $\mathrm{a}$ \\
\hline Methyl Bromide & $900 \mathrm{~g} / 10 \mathrm{~m}^{2}$ & & 83.0 & a & 92.8 & a & 9.0 & $\mathrm{a}$ \\
\hline Control without Phelipanche & 0 & & 90.8 & a & 102.3 & a & 8.8 & $\mathrm{a}$ \\
\hline Control with Phelipanche & 0 & & 87.0 & a & 90.5 & $\mathrm{ab}$ & 9.0 & $\mathrm{a}$ \\
\hline
\end{tabular}




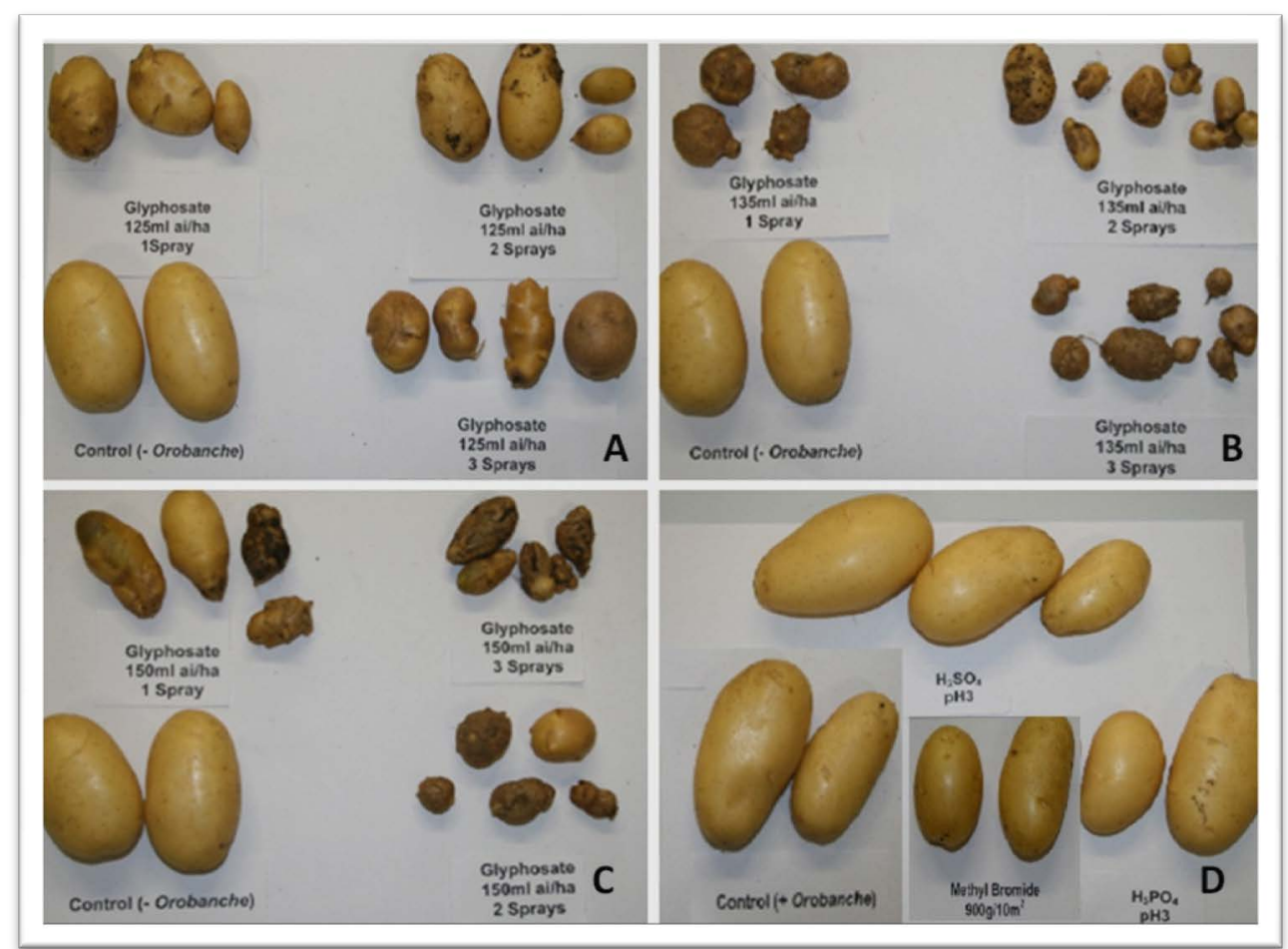

Figure 1. (A)-(C): Deformed potato tubers with cracks or fissures caused by a single or sequential application of glyphosate compared to the control or other chemicals (D).

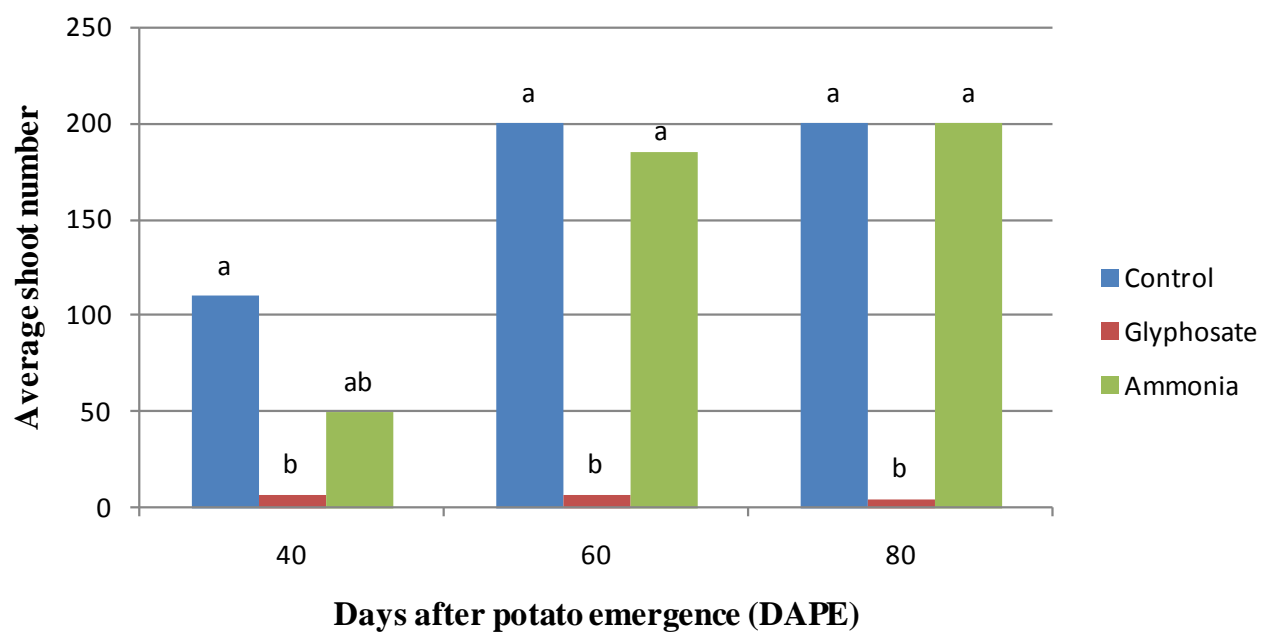

Figure 2. Effects of glyphosate and ammonia on Phelipanche aegyptiaca above ground total shoot number (SN). Data represent average of four replicates. Means followed by the same letter, within each column, do not significantly differ at the $5 \%$ level according to LSD test. DAPE: Days after potato emergence.

\subsection{Field Experiments in 2010}

Except for single application of glyphosate at 60 and $80 \mathrm{~g} \cdot \mathrm{ai} \cdot \mathrm{ha}^{-1}$ applied at 20 DAPE, all glyphosate treatments significantly reduced $P$. aegyptiaca infestation as compared to the control (Table 4). Single application of glyphosate at $100 \mathrm{~g} \cdot$ ai $\cdot \mathrm{ha}^{-1}$ at 20 DAPE resulted in significant reduction of $P$. aegyptiaca by $65 \%$ as compared to the control after 100 DAPE. Sequential application of glyphosate at 60,80 , or $100 \mathrm{~g} \cdot \mathrm{ai}^{\mathrm{i}} \mathrm{ha}^{-1}$ applied at 20, 40, and 60 DAPE were the most effective treatments in reducing $P$. aegyptiaca shoot number after 100 DAPE and 
shoot dry weight. These treatments reduced $P$. aegyptiaca infestation by $100 \%$, compared to the control (Table 4). These results demonstrate the previous observations that split application of sub lethal doses of glyphosate is recommended for the eradication of Phelipanche spp. Castejon-Munoz et al. [3] showed that glyphosate at 20 $40 \mathrm{~g} \cdot \mathrm{ha}^{-1}$ at 12 and 14 days interval eradicated more than $80 \%$ of Orobanche cemua in sunflower.

Similar to the results of the green house experiment, all applications of glyphosate (60, 80, and $100 \mathrm{~g} \cdot \mathrm{ai}^{\mathrm{i}} \mathrm{ha}^{-1}$ ) were injurious to potato plants early in the growing season (after 60 DAPE) when compared to control (Table 5). Injuries appeared 10 days after first spraying and comprised of leaf yellowing, plant stunting, and compact plants. However, injury symptoms disappeared by 75 DAPE. Single or sequential application of glyphosate at all tested dosages had no significant effect on potato shoot height 60 DAPE. However, sequential application of glyphosate at $100 \mathrm{~g} \cdot$ ai ha $^{-1}$ was toxic to potato plants and significantly reduced potato shoot height 75 DAPE.

Although single and sequential applications of glyphosate at 60 and $80 \mathrm{~g} \cdot \mathrm{ai} \cdot \mathrm{ha}^{-1}$ were injurious to potato plants early in the growing season, both rates had no negative effects on total potato quantity and quality (Table 6). While, glyphosate at $100 \mathrm{~g} \cdot \mathrm{ai} \cdot \mathrm{ha}^{-1}$ (Single or sequential) significantly reduced total potato yield and produced non-marketable tubers. Phytotoxicity was mostly reflected in the tuber quality of potato yield grown for fresh market with a high incidence of deformed and small tubers. These results are similar to the observations by Gilreath et al. [31] who observed that marketable yield of pepper declined with glyphosate dosages at 100 $\mathrm{g} \cdot \mathrm{ai} \cdot \mathrm{ha}^{-1}$. Previous studies by Nadal et al. [32] concluded that sequential application of glyphosate at 67 $\mathrm{g} \cdot \mathrm{ai} \cdot \mathrm{ha}^{-1}$ completely controlled Orobanche crenata infestation and increased seed production of narbon bean (Vicianar bonensis L), compared to the control. Thus, selectivity remains the main obstacle in various crops and it could be mediated by the rate and time of application.

Table 3. Yield response of potato to single or sequential application of sub-lethal doses of glyphosate at $125 \mathrm{~g} \cdot \mathrm{ai}^{\cdot} \mathrm{ha} \mathrm{a}^{-1}$ and injected ammonia gas at $30 \mathrm{~kg} \cdot \mathrm{ha}^{-1}$. Data represent average of four replicates. Means followed by the same letter, within each column, do not significantly differ at the 5\% level according to the LSD test. PTY: Potato tuber yield; TTN: Total tuber number; MTN: Marketable tuber number; NTN: Non-marketable tuber number.

\begin{tabular}{|c|c|c|c|c|c|c|c|c|}
\hline \multirow{3}{*}{$\begin{array}{l}\text { Treatment } \\
\text { Glyphosate }\end{array}$} & \multirow{2}{*}{\multicolumn{2}{|c|}{$\begin{array}{c}\text { PTY } \\
\text { (Tons per ha) }\end{array}$}} & \multirow{2}{*}{\multicolumn{2}{|c|}{$\begin{array}{c}\text { TTN } \\
\text { (No. per ha) }\end{array}$}} & \multirow{2}{*}{\multicolumn{2}{|c|}{$\begin{array}{c}\text { MTN } \\
\text { (No. per ha) }\end{array}$}} & \multirow{2}{*}{\multicolumn{2}{|c|}{$\begin{array}{c}\text { NTN } \\
\text { (No. per ha) }\end{array}$}} \\
\hline & & & & & & & & \\
\hline & 16.2 & a & 153809.5 & a & 54761.90 & a & 99047.60 & $\mathrm{a}$ \\
\hline Ammonia & 9.5 & $\mathrm{~b}$ & 86666.65 & b & 39047.61 & a & 47619.04 & b \\
\hline Control & 10.0 & b & 94761.89 & b & 38571.42 & a & 56190.47 & b \\
\hline
\end{tabular}

Table 4. Phelipanche aegyptiaca above ground shoot number (SN) and total shoot dry weight (TSDWT) in response to sub-lethal doses of glyphosate after 100 days after potato emergence (DAPE). Data represent average of four replicates. Means followed by the same letter, within each column, do not significantly differ at the $5 \%$ level according to the LSD test.

\begin{tabular}{|c|c|c|c|c|c|c|}
\hline \multirow{3}{*}{$\begin{array}{l}\text { Treatment } \\
\text { Glyphosate }\end{array}$} & \multirow{3}{*}{$\begin{array}{c}\text { Rate } \\
\left(\mathrm{g} \cdot \mathrm{ai} \cdot \mathrm{ha}^{-1}\right) \\
60\end{array}$} & \multirow{3}{*}{$\begin{array}{c}\text { Application time } \\
\text { (DAPE) } \\
20\end{array}$} & \multirow{2}{*}{\multicolumn{2}{|c|}{$\begin{array}{c}\text { SN } \\
\left(\text { per } m^{2}\right)\end{array}$}} & \multirow{2}{*}{\multicolumn{2}{|c|}{$\begin{array}{c}\text { TSDWT } \\
\left(\mathrm{g}_{\text {per }}{ }^{2}\right)\end{array}$}} \\
\hline & & & & & & \\
\hline & & & 31.3 & $\mathrm{a}$ & 20.5 & $\mathrm{a}$ \\
\hline & 80 & 20 & 18.0 & $\mathrm{a}$ & 14.8 & $\mathrm{a}$ \\
\hline & 100 & 20 & 9.0 & $\mathrm{~b}$ & 7.8 & $\mathrm{~b}$ \\
\hline & 60 & $20 / 40$ & 4.0 & $\mathrm{~b}$ & 2.6 & bc \\
\hline & 80 & $20 / 40$ & 2.3 & bc & 1.4 & bc \\
\hline & 100 & $20 / 40$ & 1.0 & $\mathrm{C}$ & 0.7 & bc \\
\hline & 60 & $20 / 40 / 60$ & 0.0 & $\mathrm{C}$ & 0.0 & $\mathrm{C}$ \\
\hline & 80 & $20 / 40 / 60$ & 0.0 & C & 0.0 & C \\
\hline & 100 & $20 / 40 / 60$ & 0.0 & C & 0.0 & C \\
\hline Control & & & 25.7 & $\mathrm{a}$ & 16.1 & $\mathrm{a}$ \\
\hline
\end{tabular}


Table 5. Effect of glyphosate on potato shoot height (PHT) and vigor (PVR). Data represent average of four replicates. Means followed by the same letter, within each column, do not significantly differ at the 5\% level according to the LSD test. DAPE: Days after potato emergence; PVR: Crop phytotoxicity visual rating with 0 indicating complete death and 10 no injury.

\begin{tabular}{|c|c|c|c|c|c|c|c|c|c|c|}
\hline \multirow{3}{*}{$\begin{array}{l}\text { Treatment } \\
\text { Glyphosate }\end{array}$} & \multirow{3}{*}{$\begin{array}{c}\text { Rate } \\
\left(\mathrm{g} \cdot \mathrm{ai} \cdot \mathrm{ha}^{-1}\right) \\
60\end{array}$} & \multirow{3}{*}{$\begin{array}{c}\text { Application time } \\
\text { (DAPE) } \\
20\end{array}$} & \multicolumn{4}{|c|}{ PVR (\%) } & \multicolumn{4}{|c|}{ PHT (cm) } \\
\hline & & & \multicolumn{2}{|c|}{60 DAPE } & \multicolumn{2}{|c|}{75 DAPE } & \multicolumn{2}{|c|}{60 DAPE } & \multicolumn{2}{|c|}{75 DAPE } \\
\hline & & & 7.6 & bc & 8.4 & $\mathrm{ab}$ & 58.3 & $\mathrm{a}$ & 78.4 & $a b$ \\
\hline & 80 & 20 & 7.1 & bc & 8.3 & $a b$ & 59.4 & a & 78.2 & $a b$ \\
\hline & 100 & 20 & 6.6 & c & 7.5 & bc & 54.3 & a & 66.2 & $a b$ \\
\hline & 60 & $20 / 40$ & 7.6 & bc & 7.6 & bc & 60.9 & a & 77.0 & $a b$ \\
\hline & 80 & $20 / 40$ & 7.6 & bc & 7.3 & bc & 61.2 & $\mathrm{a}$ & 68.3 & $a b$ \\
\hline & 100 & $20 / 40$ & 7.0 & bc & 6.1 & d & 56.7 & $\mathrm{a}$ & 64.0 & $\mathrm{~b}$ \\
\hline & 60 & $20 / 40 / 60$ & 8.0 & $\mathrm{~b}$ & 7.5 & bc & 64.5 & $\mathrm{a}$ & 80.7 & $a b$ \\
\hline & 80 & $20 / 40 / 60$ & 7.5 & bc & 7.4 & bc & 62.3 & $\mathrm{a}$ & 66.5 & $a b$ \\
\hline & 100 & $20 / 40 / 60$ & 7.1 & bc & 6.8 & $\mathrm{~cd}$ & 56.1 & a & 64.0 & $\mathrm{~b}$ \\
\hline Control & & & 9.0 & $\mathrm{a}$ & 9.0 & a & 69.2 & a & 82.2 & a \\
\hline
\end{tabular}

Table 6. Yield response of potato yield to glyphosate. Data represent average of four replicates. Means followed by the same letter, within each column, do not significantly differ at the 5\% level according to the LSD test. DAPE: Days after potato emergence; TPY: Total potato yield; TPN: Total potato number; MPY: Marketable potato yield; NPY: Non-marketable potato yield.

\begin{tabular}{|c|c|c|c|c|c|c|c|c|}
\hline \multirow{3}{*}{\begin{tabular}{|l} 
Treatment \\
\\
Glyphosate
\end{tabular}} & \multirow{3}{*}{$\begin{array}{c}\text { Rate } \\
\left(\mathrm{g} \cdot \mathrm{ai} \cdot \mathrm{ha}^{-1}\right) \\
60\end{array}$} & \multirow{3}{*}{$\begin{array}{c}\text { Application time } \\
\text { (DAPE) } \\
20\end{array}$} & \multirow{2}{*}{\multicolumn{2}{|c|}{$\begin{array}{c}\text { TPY } \\
\text { (t/ha) }\end{array}$}} & \multirow{2}{*}{\multicolumn{2}{|c|}{$\begin{array}{l}\text { MPY } \\
\text { (t/ha) }\end{array}$}} & \multirow{2}{*}{\multicolumn{2}{|c|}{$\begin{array}{l}\text { NPY } \\
\text { (t/ha) }\end{array}$}} \\
\hline & & & & & & & & \\
\hline & & & 33.9 & $\mathrm{a}$ & 28.3 & $\mathrm{a}$ & 5.6 & $\mathrm{a}$ \\
\hline & 80 & 20 & 29.9 & $\mathrm{a}$ & 24.0 & $\mathrm{a}$ & 5.9 & $\mathrm{a}$ \\
\hline & 100 & 20 & 25.9 & $\mathrm{~b}$ & 22.7 & $\mathrm{a}$ & 3.2 & $\mathrm{~b}$ \\
\hline & 60 & $20 / 40$ & 36.0 & $\mathrm{a}$ & 30.9 & $\mathrm{a}$ & 5.1 & $\mathrm{a}$ \\
\hline & 80 & $20 / 40$ & 29.9 & $\mathrm{a}$ & 25.4 & $\mathrm{a}$ & 4.5 & $\mathrm{a}$ \\
\hline & 100 & $20 / 40$ & 24.9 & $\mathrm{~b}$ & 19.9 & b & 5.0 & $\mathrm{a}$ \\
\hline & 60 & $20 / 40 / 60$ & 36.8 & $\mathrm{a}$ & 28.0 & $\mathrm{a}$ & 8.8 & $\mathrm{a}$ \\
\hline & 80 & $20 / 40 / 60$ & 30.2 & $\mathrm{a}$ & 23.5 & $\mathrm{a}$ & 6.7 & $\mathrm{a}$ \\
\hline & 100 & $20 / 40 / 60$ & 20.4 & $\mathrm{~b}$ & 14.3 & $\mathrm{~b}$ & 6.1 & $\mathrm{a}$ \\
\hline Control & & & 26.9 & $\mathrm{a}$ & 20.6 & $\mathrm{a}$ & 6.3 & $\mathrm{a}$ \\
\hline
\end{tabular}

\section{Conclusion}

Our results suggest that sequential foliar application $(20+40$ and $20+40+60$ DAPE) of glyphosate at $60-80$ $\mathrm{g} \cdot \mathrm{ai}^{\cdot} \mathrm{ha}^{-1}$ could be used selectively to reduce $P$. aegyptiaca infection in potato. The timing of glyphosate application is crucial for successful control of $P$. aegyptiaca and could vary among potato varieties and growing seasons. Additional research is required to determine the optimum timing of glyphosate application and duration of control based on estimated $P$. aegyptiaca phenological underground growth stages in the field.

\section{References}

[1] Abou-Jawdah, Y., Sobh, H. and Saad, A.T. (2001) Incidence of Potato Virus Diseases and Their Significance for a Seed Certification Program in Lebanon. Phytopathologia Mediterranea, 40, 113-118.

[2] Joel, D.M., Hershenhorn, J., Eizenberg, H., Aly, R., Ejeta, G., Rich, P., Ransom, J., Sauerborn, J. and Rubiales, D. 
(2007) Biology and Management of Weedy Root Parasites. Horticultural Reviews, 33, 207-349. http://dx.doi.org/10.1002/9780470168011.ch4

[3] Parker, C. and Riches, C.R. (1993) Parasitic Weeds of the World: Biology and Control. Cab Intl, Wallingford, UK, 332.

[4] Sabra, A. and Haidar, M.A. (2012) Invasive Weed Mapping of Lebanon. Journal of Agricultural Science and Technology B, 2, 1010-1015.

[5] Haidar, M. and Bibi, W. (1995) Common Weeds of Lebanon. Arab and Near East Plant Protection Newsletter. Abstract, 34.

[6] Eizenberg, H., Colquhoun, J.B. and Mallory-Smith, C.A. (2006) Imazamox Application Timing for Small Broomrape (Orobanche minor) Control in Red Clover. Weed Science, 54, 923-927. http://dx.doi.org/10.1614/WS-05-151R.1

[7] Eizenberg, H., Hershenhorn, J., Ephrath, J. and Kanampiu, F. (2013) The Complexity of Chemical Control of Parasitic Weeds. In: Joel, D.M., Gressel, J. and Musselman, L.J., Eds., Parasitic Orobanchaceae Parasitic Mechanisms and Control, Springer, Berlin, 415-423. http://dx.doi.org/10.1007/978-3-642-38146-1_23

[8] Elzein, A. and Kroschel, J. (2003) Progress on Management of Parasitic Weeds. In: Labrada, R, Ed., Weed Management for Developing Countries, FAO Plant Production and Protection Paper, 109-143.

[9] Haidar, M. and Sidahmad, M. (2000) Soil Solarization and Chicken Manure for the Control of Orobanche crenata and Other Weeds in Lebanon. Crop Protection, 19, 169-173. http://dx.doi.org/10.1016/S0261-2194(99)00083-6

[10] Haidar, M. and Sidahmed, M.M. (2006) Elemental Sulfur and Chicken Manure for the Control of Branched Broomrape (Orobanche ramosa). Crop Protection, 25, 47-51. http://dx.doi.org/10.1016/j.cropro.2005.03.022

[11] Haidar, M., Bibi, W. and Sidahmad, M.M. (2003) Response of Branched Broomrape (Orobanche ramosa) Growth and Development to Various Soil Amendments in Potato. Crop Protection, 22, 291-294. http://dx.doi.org/10.1016/S0261-2194(02)00150-3

[12] Hershenhorn, J., Plakhine, D., Goldwasser, Y., Westwood, J.H., Foy, C.L. and Kleifeld, Y. (1998) Effect of Sulfonylurea Herbicides on Early Development of Egyptian Broomrape (Orobanche aegyptiaca) in Tomato (Lycopersicon esculentum). Weed Technology, 12, 108-114.

[13] Joel, D.M., Gressel, J. and Musselman, L.J. (2013) Parasitic Orobanchaceae: Parasitic Mechanisms and Control. Springer, Berlin, 513 p. http://dx.doi.org/10.1007/978-3-642-38146-1

[14] Kasasian, L. (1973) Control of Orobanche. Proceedings of the National Academy of Sciences of the United States of America, 19, 368-371. http://dx.doi.org/10.1080/09670877309412782

[15] Castejon-Munoz, M., Romero-Munoz, F. and Garcia Torres, L. (1990) Control of Broomrape (Orobanche cernua Loelf) in Sunflower (Helianthus annus L.) with Glyphosate. Crop Protection, 9, 332-336. http://dx.doi.org/10.1016/0261-2194(90)90002-O

[16] Kotoula-Syka, E. and Eleftherohorinos, I.G. (1990) Orobanche ramosa L. (Broomrape) Control in Tomatoes (Lycopersicon esculentum Mill.) with Chlorosulfuron, Glyphosate and Imazaquin. Weed Research, 31, 19-27. http://dx.doi.org/10.1111/j.1365-3180.1991.tb01738.x

[17] Nandula, V., Foy, C. and Orcutt, D. (1999) Glyphosate for Orobanche aegyptiaca Control in Vicia sativa and Brassica napus. Weed Science, 47, 486-491.

[18] Abu-Irmaileh, B. (1994) Nitrogen Reduces Branched Broomrape (Orobanche ramosa) Seed Germination. Weed Science, 42, 57-60.

[19] Westwood, J.H. and Foy, C.L. (1999) Influence of Nitrogen on Germination and Early Development of Broomrape (Orobanche spp.). Weed Science, 47, 2-7.

[20] Simpson, K. (1986) Fertilizers and Manures. Longman Group Limited, New York, 254.

[21] Gressel, J. and Joel, D.M. (2013) Weedy Orobanchaceae: The Problem. In: Joel, D.M., Gressel, J. and Musselman, L.J., Eds., Parasitic Orobanchaceae: Parasitic Mechanisms and Control, Springer, Berlin, 309-312. http://dx.doi.org/10.1007/978-3-642-38146-1_17

[22] Goldwasser, Y., Eizenberg, H., Golan, S., Hershenhorn, J. and Kleifeld, Y. (2001) Orobanche aegyptiaca Control in Potato. Crop Protection, 20, 403-410. http://dx.doi.org/10.1016/S0261-2194(00)00162-9

[23] Goldwasser, Y., Eizenberg, H., Golan, S. and Kleifeld, Y. (2003) Control of Orobanche crenata and Orobanche aegyptiaca in Parsley. Crop Protection, 22, 295-305. http://dx.doi.org/10.1016/S0261-2194(02)00152-7

[24] Nemli, Y., Emiroglu, U. and Kucukozden, R. (1991) Chemical Control of Broomrape (Orobanche ramosa L.) in Tobacco. In: Weymann, K. and Musselman, L.J., Eds., Proceedings of the International Workshop on Orobanche Research, Eberhard-Karls-Universitat, Tubingen, 191-199.

[25] Vasilakakis, C.B., Vezirtjoglou, R.M. and Hadzistavros, C.S. (1988) The Effect of Polydynamic Agrochemicals on the 
Broomrape (Orobanche ramose L.) of Tobacco in the Field. Bulletin d'Information, 8, 146-147.

[26] Zahran, M.K. (1970) Satisfactory Control of Orobanche crenata in Broad Beans by Soil Fumigation in UAR. Proceedings of the British Weed Control Conference, 10, 680-684.

[27] Ruzo, L.O. (2006) Physical, Chemical and Environmental Properties of Selected Chemical Alternatives for the Pre-Plant Use of Methyl Bromide as a Soil Fumigant. Pest Management Science, 62, 99-113. http://dx.doi.org/10.1002/ps.1135

[28] Jain, R. and Foy, C.L. (1992) Nutrient Effects on Parasitism and Germination of Egyptian Broomrape (Orobanche aegyptiaca). Weed Technology, 6, 269-275.

[29] Dörr, I. and Kollmann, R. (1995) Symplasmic Sieve Element Continuity between Orobanche and Its Hosts. Botanica Acta, 108, 47-55. http://dx.doi.org/10.1111/j.1438-8677.1995.tb00830.x

[30] Walker, E.R. and Oliver, L.R. (2008) Translocation and Absorption of Glyphosate in Flowering Sicklepod (Senna obtusifolia). Weed Science, 56, 338-343. http://dx.doi.org/10.1614/WS-07-069.1

[31] Gilreath, J.P., Locascio, S.J. and Chase, C.A. (2000) Phytotoxic Effects of Glyphosate on Pepper (Capsicum annuum). Weed Technology, 14, 488-494. http://dx.doi.org/10.1614/0890-037X(2000)014[0488:PEOGOP]2.0.CO;2

[32] Nadal, S., Moreno, M.T. and Roman, B. (2008) Control of Orobanche crenata in Vicianar bonensis by Glyphosate. Crop Protection, 27, 873-876. http://dx.doi.org/10.1016/j.cropro.2007.10.009 